\title{
Proximate Analysis, Mineral and Phytochemical Composition of Euphorbia Hyssopifolia
}

\author{
*Igwenyi, I.O., Agwor, A. S., Nwigboji, I. U., Agbafor, K. N. And Offor, C. E. \\ ${ }^{1}$ Department of Biochemistry, Ebonyi State University, Abakaliki, Ebonyi State, Nigeria.
}

\begin{abstract}
Euphorbia hyssopifolia is a herbaceous plant found in Nigeria and is used as a purgative both in the eastern and northern parts of the country. Extracts of the leaves are used in the treatment of constipation or inducement of purging to control weight and/or shape. Despite its toxicity and clinical use, analyses of its proximate and mineral composition, as well as the phytochemical analysis revealed other possible applications of the plant. Proximate analysis showed high moisture content of $83.00 \%$, crude fat $3.20 \%$, ash content $3.80 \%$, crude fiber $2.15 \%$, protein $0.88 \%$ and carbohydrate content of $6.98 \%$. Analysis of mineral composition revealed the presence of some minerals in $\mathrm{mg} / \mathrm{g}$ such as calcium 0.042, sodium 0.002, potassium 0.002, magnesium 0.003 , lead $1.890 \times 10^{-3}$, iron $0.034 \times 10^{-3}$, and manganese $0.133 \mathrm{mg} / \mathrm{g}$. Phytochemical screening revealed the presence of alkaloids, flavonoids, carbohydrate, vitamin A, reducing sugars, saponnins, glycosides and steroidal aglycone. The quantitative analysis showed that the leaves contained $281.25 \pm 3.84 \mathrm{mg} / 100 \mathrm{~g}$ of flavonoids, $402.18 \pm 10.38 \mathrm{mg} / 100 \mathrm{~g}$ of sugars, $216.67 \pm 8.57 \mathrm{mg} / 100 \mathrm{~g}$ of alkaloids, $182.60 \pm 6.27 \mathrm{mg} / 100 \mathrm{~g}$ of steroids, $3.96 \pm 0.51 \mathrm{mg} / \mathrm{Kg}$ of saponnins, $30.71 \pm 2.32 \mathrm{mg} / \mathrm{Kg}$ of tannins, $0.002 \pm 0.00 \mathrm{mg} / 100 \mathrm{~g}$ of cyanide and $0.4026 \pm 0.30 \%$ of proteins. These results showed that Euphorbia hyssopifolia is endowed with many active principles, minerals and organic matter that can be found useful in medicinal/therapeutic activities as well as possible application in nutrition and pharmacology.
\end{abstract}

Key words: Euphorbia hyssopifolia, proximate composition, phytochemicals, minerals elements.

\section{Introduction}

Plants have been used as sources of food and medicine. The most ancient approach to curing sicknesses and diseases is herbalism (Apata, 1979). The plant Euphorbia hyssopifolia is commonly found in the tropical and sub-tropical regions of Africa and in America (Adedapo et al., 2004). It produces caustic latex, which constitute a health hazard to humans and livestock (Abo, 1994). The toxic effects of Euphorbia hyssopifolia have a diuretic and purgative action. It is known to have medicinal effect for inflammation of the respiratory track, while for asthma, it has a reputation for inducing bronchial relaxation (Adedapo et al., 2004). The plant is taken as tea for colds, indigestion and for back pains and sometimes taken as a tonic (Abo, 1994).

Medicinally and even toxic plants have the potentials of helping in the search for more potent and less toxic medicinal agents when thoroughly investigated. Although many plants have been credited with curative and/or toxic attributes in Nigeria and many other African countries, only few are of proven status and even less are clinically useful (Ojewole, 983). The investigation into the proximate and mineral composition as well as the phytochemical screening will serve as a prelude to the mechanism of action and other possible applications of the material. This study is important primarily due to the common use of this plant crude extract in rural communities of the South-east areas of Nigeria in inducing emptying of the bowel and in checking weight and treatment of constipation.

\section{Materials And Methods}

Fresh leaves of Euphorbia hyssopifolia were harvested from the vegetation around Ebonyi State University, PRESCO Annex, Abakaliki, Ebonyi State. There were thoroughly washed, dried and ground while chemicals of high analytical grade were used in the research.

\section{Methods:}

PROXIMATE ANALYSES: This is the evaluation of the nutritional value and organic content of the plant materials. This will be achieved by the measure of percentage proximate composition which includes the quantification of the amount of protein, lipid, carbohydrate, moisture, fiber and ash using the Official methods of analyses of AOAC (1980).

PHYTOCHEMISTRY: Phytochemistry is concerned with the enormous variety of organic substances that are elaborated and accumulated by plants and deals with the chemical structure of these substances, their metabolism, natural distribution and biological function (Harborne, 1973). Some of these plants have some antinutritional factors which are toxic and can cause impaired absorption of essential nutrients there in (Kaul, 1975). 
Quantification of phytochemicals involves the use of various methods in determining the amount of bioactive compounds in the plant material (Kabir, 2005). Phytochemical tests were carried out to determine the presence or otherwise, the absence of alkaloids, flavonoids, glycosides (such as cardiac, cyanogenic, anthrancene and Oand C-glycosides and steroidal aglycone), saponnins, and tannins. Standard phytochemical methods were employed in these analyses (Harborne, 1973; Kelvin and Butler, 1999).

MINERAL ANALYSIS: Various photometric and titrimetric methods shall be used in the quantification of these essential nutrients. Such mineral elements include Calcium $(\mathrm{Ca})$, Iron $(\mathrm{Fe})$, Copper $(\mathrm{Cu})$, Manganese $(\mathrm{Mn})$, Phosphorus (P), Manganese (Mn) and so on.

Mineral analyses shall be carried out using Buck Scientific Atomic Absorption/Emission Spectrophotometry (AAS) and Molybdemun blue method for phosphorus.

\section{Result}

Table 1: Result of proximate composition.

\begin{tabular}{|c|c|}
\hline \multicolumn{2}{|c|}{ PROXIMATE COMPOSITION (\%) } \\
\hline Moisture & $83.00 \pm 0.24$ \\
\hline Crude fat & $3.20 \pm 0.03$ \\
\hline Ash content & $3.80 \pm 0.02$ \\
\hline Crude fiber & $2.15 \pm 0.04$ \\
\hline Protein & $0.88 \pm 0.01$ \\
\hline Carbohydrate & $6.98 \pm 0.02$ \\
\hline
\end{tabular}

Table 2: Mineral analysis of Euphorbia hyssopifolia.

\begin{tabular}{|c|c|}
\hline \multicolumn{2}{|c|}{ MINERAL CONTENT IN mg/g } \\
\hline Calcium & 0.042 \\
\hline Sodium & 0.002 \\
\hline Potassium & 0.002 \\
\hline Magnesium & 0.003 \\
\hline Lead & $1.890 \times 10^{-3}$ \\
\hline Iron & $0.034 \times 10^{-3}$ \\
\hline Manganese & 0.134 \\
\hline
\end{tabular}

Table 3: Quantitative phytochemical analysis on Euphorbia hyssopifolia.

\begin{tabular}{|c|c|}
\hline PHYTOCHEMICAL & CONCENTRATION IN mg/Kg \\
\hline Flavonoids & $28.125 \pm 3.84$ \\
\hline Alkaloids & $21.667 \pm 8.57$ \\
\hline Steroids & $18.260 \pm 6.27$ \\
\hline Cyanides & $0.0002 \pm 0.00$ \\
\hline Saponnins & $3.96 \pm 0.51$ \\
\hline Tannins & $30.71 \pm 2.32$ \\
\hline Sugars & $40.218 \pm 10.38$ \\
\hline Proteins & $0.4026 \pm 0.30 \%$ \\
\hline
\end{tabular}

\section{Discussion And Conclusion}

Generally, the nutritional quality of food materials may be evaluated by biochemical analysis of the food for proximate composition. Mineral elements also are needed in minute quantities for the proper functioning of the human system, health growth and development. Proximate analysis as shown in table 1 revealed that it had high moisture content of $83.00 \%$, crude fat $3.20 \%$, ash content $3.80 \%$, crude fiber $2.15 \%$, protein $0.88 \%$ and carbohydrate content of $6.98 \%$. The moisture content showed the storage of the leaves can be achieved by careful reduction in moisture content to avoid microbial growth and deterioration. The carbohydrate content as well as lipid and protein showed that the leaves may not serve as a good source of dietary energy since a large quantity must be consumed to furnish a reasonable amount of dietary nutrients to satisfy nutrition. The level of ash (minerals) and plants secondary metabolites indicated that the plant may serve a medicinal and therapeutic function rather than dietary requirement.

Analysis of mineral composition revealed the presence of some minerals in $\mathrm{mg} / \mathrm{g}$ such as calcium 0.042 , sodium 0.002 , potassium 0.002 , magnesium 0.003 , lead $1.890 \times 10^{-3}$, iron $0.034 \times 10^{-3}$, and manganese $0.133 \mathrm{mg} / \mathrm{g}$. The result revealed a high concentration of calcium compared to other minerals. These minerals play significant roles in several biological processes. Bone growth and turnover are influenced and regulated by the metabolism of $\mathrm{Ca}$, phosphate and $\mathrm{Mg}$; Fe is important in the formation of haemoglobin. $\mathrm{Mg}$ and $\mathrm{K}$ are also involved in inducement of calmness (Burtis and Ashwood 2003).

Phytochemical screening revealed the presence of alkaloids, flavonoids, carbohydrate, vitamin A, reducing sugars, saponnins, glycosides and steroidal aglycone. The quantitative analysis showed that the leaves contained $281.25 \pm 3.84 \mathrm{mg} / 100 \mathrm{~g}$ of flavonoids, $402.18 \pm 10.38 \mathrm{mg} / 100 \mathrm{~g}$ of sugars, $216.67 \pm 8.57 \mathrm{mg} / 100 \mathrm{~g}$ of 
alkaloids, $182.60 \pm 6.27 \mathrm{mg} / 100 \mathrm{~g}$ of steroids, $3.96 \pm 0.51 \mathrm{mg} / \mathrm{Kg}$ of saponnins, $30.71 \pm 2.32 \mathrm{mg} / \mathrm{Kg}$ of tannins, $0.002 \pm 0.00 \mathrm{mg} / 100 \mathrm{~g}$ of cyanide and $0.4026 \pm 0.30 \%$ of proteins. Alkaloids have analgesic effects while flavonoids act as antioxidants in biological systems. Other properties of flavonoids include protection against allergies, inflammation, free radicals, microbes, ulcers, hepatoxins, viruses and tumors (Okwu and Ndu, 2006). Morphine alkaloids are powerful pain relievers and narcotics (induces sleep or drowsiness). Atropine, cocaine and other alkaloids are known stimulants of the central nervous system. (Teguja and Omak, 1993). Tannins prevent urinary tract infection by preventing bacteria from adhering to the walls. Tannins have been shown to be useful in the management of HIV infection and herpes. Combination of tannin and anthocyanins can breakdown cholesterol in the bloodstream and in atherosclerotic plaques. Tannins, along with vitamin $\mathrm{C}$ help build and strengthen collagen (Okuda et al., 1991). Saponins serve as natural antibiotics, which help body to fight infections and microbial invasions. They also enhance the effectiveness of certain vaccines, lower cholesterol and knock out some tumor cells, particularly lung and blood cancers (Okwu and Ndu, 2006).

\section{References}

[1] Abo, K. A. (1994). Characterization of ingenol, an inflammatory diterpene from some Nigerian Euphorbia species. Afrrcan Journal of Medical Sciences. 23: 161-163.

[2] O. A. C. (1980). Official methods of analysis (13 ${ }^{\text {th }}$ edition), Association of Official Analytical Chemists, Washington DC

[3] Abo, K. A. (1994). Characterization of Ingenol: An inflammatory diterpene from some Nigerian Euphorbia and Eleaphorbia species. African Journal of Medical Science, 23: 161-163.

[4] Adedapo, A. A., Obatan, M. O. and Olorunsogo, O. O. (2004). Toxic effect of some plants in the genus Euphorbia on hematological and biochemical parameters of rats. Vetenary Archive. 74: 53-62.

[5] Apata, L. (1979). The practice of herbalism in Nigeria: in African medicinal plants, University of Ife press, Ile-Ife, Nigeria. 13-19.

[6] Harborne, J. B. (1973). Phytochemical methods: a uide to modern techniques of plant analysis. $1^{\text {st }}$ edition. Chang and Hall, London.

[7] Kabir, O. A., Olukayode, O., Chidi, E. O., Christopher, C. I. and Kehinde, A. F. (2005). Screening of crude extracts of six medicinal plants used in south-west Nigeria. Unorthodox medicine for anti-methicillin resistant Staphylococcus aureus activity, Complementary and Alternative medicine, 5: 6.

[8] Kaul, A. K. (1975). Agronomic Comparism of dwarf and tall napier grass in Puerto Rico. Journal of Agriculture of University of Puerto Rico. 81: (1/2) 9-18.

[9] Kelvin, K. J. and Butler, F. H. (1999). Phytochemical methods: a guide to modern techniques in plant analysis. $1^{\text {st }}$ edition. Chang and Hall, London. 